\title{
Sonerila longipedunculata sp. nov., a new species of Melastomataceae from the southern Western Ghats, India, with additional notes and lectotypification of Sonerila travancorica
}

\author{
Sekarathil RESMI ${ }^{1} \&$ Santhosh NAMPY ${ }^{2, *}$ \\ ${ }^{1,2}$ Department of Botany, University of Calicut, Malappuram District, Kerala - 673 635, India. \\ *Corresponding author: santhoshnampy2019@gmail.com \\ ${ }^{1}$ Email: resmischandran1991@gmail.com
}

\begin{abstract}
A new species of Melastomataceae, Sonerila longipedunculata Resmi \& Nampy sp. nov., is described from the southern Western Ghats, India. It is morphologically close to $S$. travancorica, but differs by the tuberous root stock, fleshy stems, ovate to cordate lamina, longer, angular peduncles, 3-ribbed hypanthium, ovate-elliptic petals, acute anthers, and 3-ribbed capsules. Detailed description, distribution map, and photographic images are provided. The morphological differences with relevant species are discussed. The status of the new species is provisionally assessed here as 'critically endangered' according to IUCN Red List Categories and Criteria. The name Sonerila travancorica is lectotypified and its identity is discussed. The status of Sonerila longipetiolata is discussed and is synonymised under $S$. travancorica.
\end{abstract}

Keywords. Sonerileae, Kerala, Sonerila longipetiolata, tuberous, South Wayanad forest division.

Resmi S. \& Nampy S. 2021. Sonerila longipedunculata sp. nov., a new species of Melastomataceae from the southern Western Ghats, India, with additional notes and lectotypification of Sonerila travancorica. European Journal of Taxonomy 733: 160-174. https://doi.org/10.5852/ejt.2021.733.1231

\section{Introduction}

Sonerila Roxb. (Melastomataceae Juss., Sonerileae Triana) is a taxonomically complex genus with around 180 recognised taxa of terrestrial or low epiphytic herbs and sub-shrubs of shady habitats (Resmi \& Nampy 2018). The genus is distributed in the tropical Indo-Pacific region (Cellinese 1997), and is easily recognisable by its generally trimerous flowers, mostly uniparous (scorpioid) cymes, and 3-locular, inferior ovary. Clarke (1879) recognised 43 species in the Flora of British India, ca 20 species of which are found within the present political boundaries of India. Currently, there are 62 species and two varieties reported in India, with the highest diversity (53 species and two varieties) in the Western Ghats, one of the major centres of diversity for the genus (Resmi et al. 2018).

During botanical explorations in 2017-2019, as part of a taxonomic revision of Sonerila in India, an unknown species was collected in the southern Western Ghats, from the Kattukunnu of Banasura hills, within the South Wayanad forest division, Kerala. Following a careful review of herbarium specimens and taxonomic literature, we conclude that this species is new to science. The new species, Sonerila 
longipedunculata Resmi \& Nampy sp. nov., is described and compared with Sonerila travancorica Bedd., a species described from the Travancore mountains by Beddome (1871). Further scrutiny revealed that, even though later researchers included the latter species in their studies (Triana 1871; Clarke 1879; Cogniaux 1891; Stapf 1892; Gamble 1919; Nair \& Henry 1983; Mohanan \& Henry 1994; Mohanan \& Sivadasan 2002; Manickam et al. 2008), a type had not been designated, and hence we selected a lectotype according to the Shenzhen Code (Turland et al. 2018). We also came across the recently described species S. longipetiolata Josephine, Manickam, Murugan, Sundaresan \& Jothi (Josephine et al. 2003), which was differentiated from S. travancorica based on size and shape of leaves, texture of indumentum, number of flowers, and apex shape of calyx and corolla. However, a detailed examination of the protologue, type, and live material from the type locality revealed that the vegetative and floral features used to delimit $S$. longipetiolata are variable and overlap with the circumscription of $S$. travancorica. Therefore, we reduce $S$. longipetiolata to a synonym of $S$. travancorica.

\section{Material and methods}

All measurements and morphological character assessments were performed using living samples in the field and cultivated specimens at Calicut University Botanical Garden. Specimens were processed following Vogel (1987) and Forman \& Bridson (1989). The study was based on specific literature (Triana 1871; Beddome 1871; Clarke 1879; Cogniaux 1891; Stapf 1892; Gamble 1919; Nair \& Henry 1983; Mohanan \& Henry 1994; Mohanan \& Sivadasan 2002; Josephine et al. 2003; Manickam et al. 2008). All available Indian specimens of Sonerila, including types, were examined in the following herbaria: BM, CAL, CALI, K, MH, TBGT, XCH. Acronyms of herbaria follow Index Herbariorum (Thiers, continuously updated). Specimen images were retrieved from JSTOR Global Plants (http://plants.jstor.org). Nomenclature was checked in Tropicos (http://www.tropicos.org) and the International Plant Names Index (http://www.ipni.org). For the description of taxa, the terminology follows Stearn (1992). Photographs were taken with an EZ4 HD stereo microscope with a 3.0 megapixel digital camera (Leica, Switzerland) and a Stemi 508 stereo microscope (Carl Zeiss, Germany) with an attached Axiocam 105 colour camera. Ecological and geographic distribution data were collected from herbarium labels; the distribution map was created using QGIS ver. 3.12.2 (QGIS 2020). Provisional conservation status assessments were based on guidelines published by the IUCN Standards and Petitions Subcommittee (2019).

\section{Results}

Order Myrtales Juss. ex Bercht. \& J.Presl

Family Melastomataceae Juss.

Genus Sonerila Roxb.

Sonerila longipedunculata Resmi \& Nampy sp. nov. urn:lsid:ipni.org:names:77214918-1

Figs $1-3,4 \mathrm{~A} 1-\mathrm{G} 1$

\section{Diagnosis}

Morphologically similar to $S$. travancorica in having caulescent habit, densely pubescent, long petiolate leaves, densely glandular-pubescent hypanthium and abaxially glandular-hairy petals, but differs by its tuberous root stock (vs non-tuberous in S. travancorica), fleshy stems with whitish or claret coloured bristles (vs woody stems with long, dense white hairs), 2-4-cm-long internodes (vs 2.5-6.5-cm-long internodes), 5-9-cm-long petioles with dense bristles (vs 2-7-cm-long petioles with long, dense hairs), ovate to cordate lamina with serrate margins (vs ovate to elliptic lamina with serrulate margins), 10-16-cm-long, angular peduncles (vs 3-6-cm-long, terete peduncles), 3-ribbed hypanthium (vs 6-ribbed hypanthium), ovate-elliptic petals with acute to mucronate apex (vs ovate to broadly ovate 
petals with mucronate or emarginate apex), acute anthers (vs acuminate to rostrate anthers) and 3-ribbed capsules (vs 6-ribbed capsules).

\section{Etymology}

The epithet 'longipedunculata' refers to the characteristically long peduncle of the inflorescence of the new species.

\section{Material examined}

\section{Type}

INDIA • Kerala, Wayanad district, Banasura hills, Kattukunnu; ca $1000 \mathrm{~m}$ a.s.l.; growing under wet rocks in grassy slopes; 13 Aug. 2017; Resmi S. \& Santhosh Nampy 151222; holotype: CALI!; isotype: MH!.

\section{Additional material}

INDIA • Kerala, Wayanad district, Banasura hills, Kattukunnu; ca $1000 \mathrm{~m}$ a.s.1.; on humus-covered soil and rock crevices; 8 Oct. 2017; Resmi S., Dani Francis \& Aswathy Ganga 151239; CALI!.

\section{Description}

Erect or procumbent perennial herbs, $10-30 \mathrm{~cm}$ tall. Root stocks tuberous; tubers globose, $1-1.5 \mathrm{~cm}$ in diameter, white to pale green, covered by tufts of roots. Stems sub-terete with shallow grooves arising from axils of each pair of leaves, 3-5 mm thick, fleshy, claret coloured, with 2 or 3 branches occasionally developing from distal nodes; internodes $2-4 \mathrm{~cm}$ long; nodes densely glandular- or eglandular-hairy. Leaves simple, decussate; petioles adaxially grooved or canaliculated, $5-9 \times 0.1-0.2 \mathrm{~cm}$, claret coloured with dense glandular or eglandular bristles; laminae ovate, basal ones cordate to broadly ovate, 3-6× 3-6 cm, dark green adaxially, claret coloured abaxially, cordate or sub-rounded at base with nonoverlapping or overlapping margins (basal ones), obtuse or rounded at apex, serrate at margins with each tooth ending in terminal eglandular trichome, bullate when mature, with eglandular bristles densely on adaxial surface and on midrib and lateral veins abaxially; veins pinnate, 1-2 pairs from base and 2-3 pairs from above, less branched, impressed adaxially, conspicuous abaxially. Cymes scorpioid of 6-14 flowers in two rows, terminal, unbranched; peduncles angular, 10-16 $\times 0.15-0.2 \mathrm{~cm}$, longer than petiole, densely glandular-pubescent; bracts caducous. Flowers 1-1.6 $\times 1-1.5 \mathrm{~cm}$; pedicels terete, $4-5 \times$ 1-2 mm, longer in fruit, claret coloured, densely glandular-pubescent. Hypanthium campanulate, 5-6× 2-3 mm, 3-lobed, 3-ribbed, claret coloured with greenish tinge distally, densely glandular-pubescent; lobes triangular, $1-2 \times 1-2 \mathrm{~mm}$, acute at apex. Petals 3 , ovate to elliptic, $7-8 \times 4-5 \mathrm{~mm}$, pale pink with darker midrib, obtuse to rounded at base, acute to mucronate at apex, glabrous adaxially, with glandular trichomes on midrib abaxially. Stamens 3, alternate to petals; filaments 4-5 mm long, pale pink, glabrous, dilated and twisted downwards; anthers sagittate to deeply cordate at base, acute at apex, 4-5 mm long, yellow, dehiscing through apical pores. Ovary inferior, 2-2.5 $\times 2-3 \mathrm{~mm}$; style filiform, 8-9 mm long, pale pink, dark towards apex, longer than stamen; stigma capitate, pink, rugose, glabrous. Capsules urceolate, 5-9 $\times 3-3.5 \mathrm{~mm}$, claret coloured or green with claret tinge, 3-ribbed, with sparse bristly trichomes. Seeds many, obovoid, $0.5-0.6 \mathrm{~mm}$ long, pale brown; raphe prominent, excurrent; testa densely tuberculate throughout.

\section{Phenology}

Sonerila longipedunculata sp. nov. was collected with flowers and fruits from September to October. 


\section{Distribution and habitat}

The new taxon is presently known only from a small area in the Kattukunnu of Banasura hills within the South Wayanad forest division (Fig. 1), where it has been growing under wet rocks on grassy slopes at an elevation of ca $1000 \mathrm{~m}$. Although no detailed ecological studies have been undertaken, S. longipedunculata sp. nov. appears to be restricted to shaded rocky outcrops and is likely to occur in areas where a specific combination of light intensity and moisture prevails, such as vertical, mosscovered rocks or rock crevices, as is the case for many species of Sonerila. It is found in association with S. raghaviana Ratheesh, Sunil, Nandakumar \& Shaju, species of grass (Poaceae Barnhart), Mitracarpus Zucc. (Rubiaceae Juss.), Selaginella P.Beauv. (Selaginellaceae Willk.) and several mosses.

\section{Provisional conservation status}

Sonerila longipedunculata sp. nov. is known from a single population in the type locality with about 60 mature individuals. The Area of Occupancy (AOO) is less than $10 \mathrm{~km}^{2}$. No anthropogenic threat was detected as the area falls under a protected forest. However, this area is prone to landslides due to heavy rain, which has occurred in previous years. The habitat has been affected by climate-induced draught after the unexpected floods in 2018 and 2019. We suggest the status of S. longipedunculata sp. nov. as Critically Endangered (CR) B1ab(ii) + B2ab(ii) according to IUCN (2019) criteria.

\section{Notes}

The new species is remarkable by the presence of a tuberous root stock (Fig. 2C-E), a feature seen in some of the South Indian caulescent species of Sonerila that is apparently absent in Sri Lankan

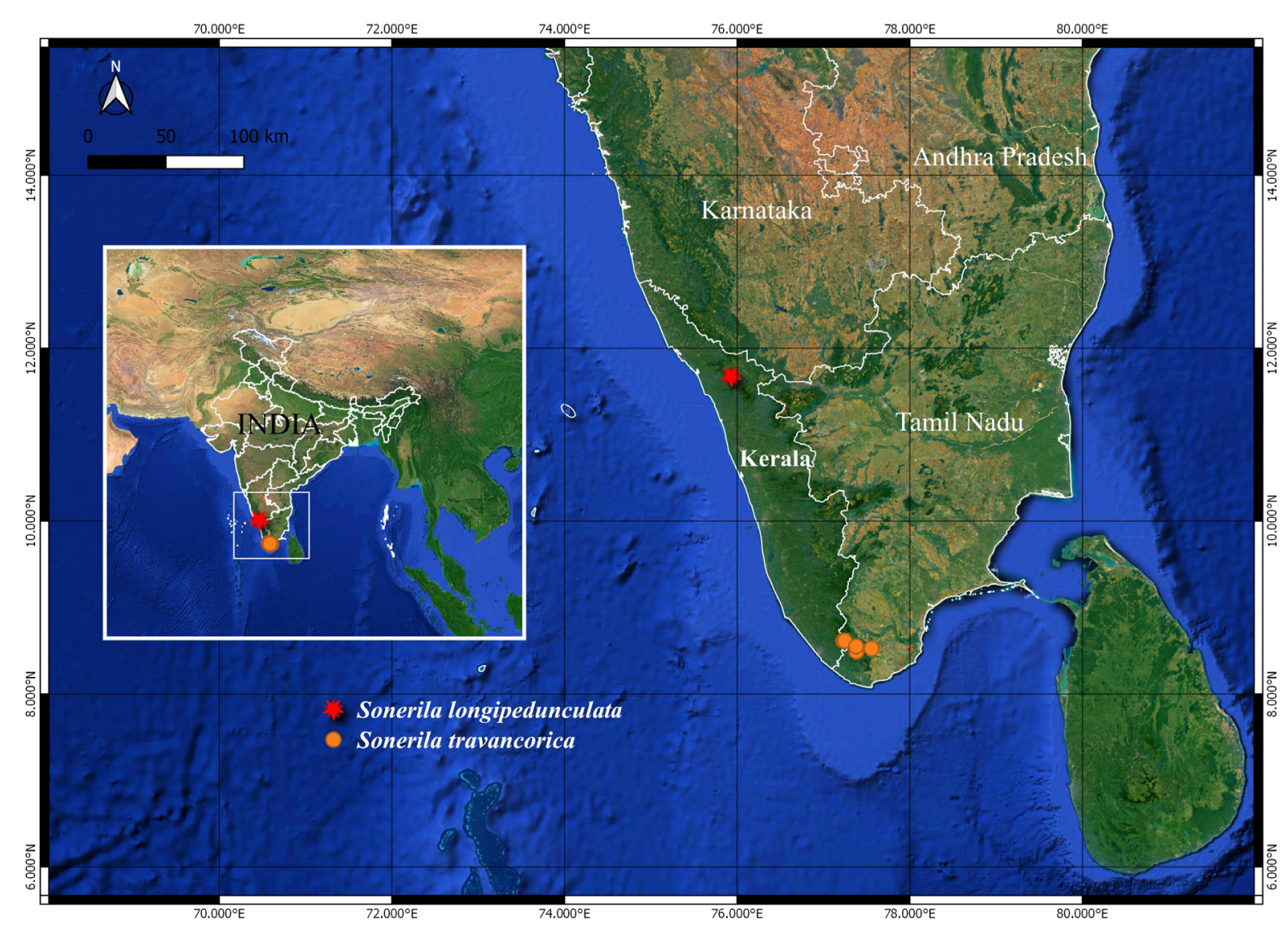

Fig. 1. Map showing the distribution of Sonerila longipedunculata Resmi \& Nampy sp. nov. and S. travancorica Bedd.; prepared by Resmi S. using QGIS ver. 3.12.2 (QGIS 2020). 


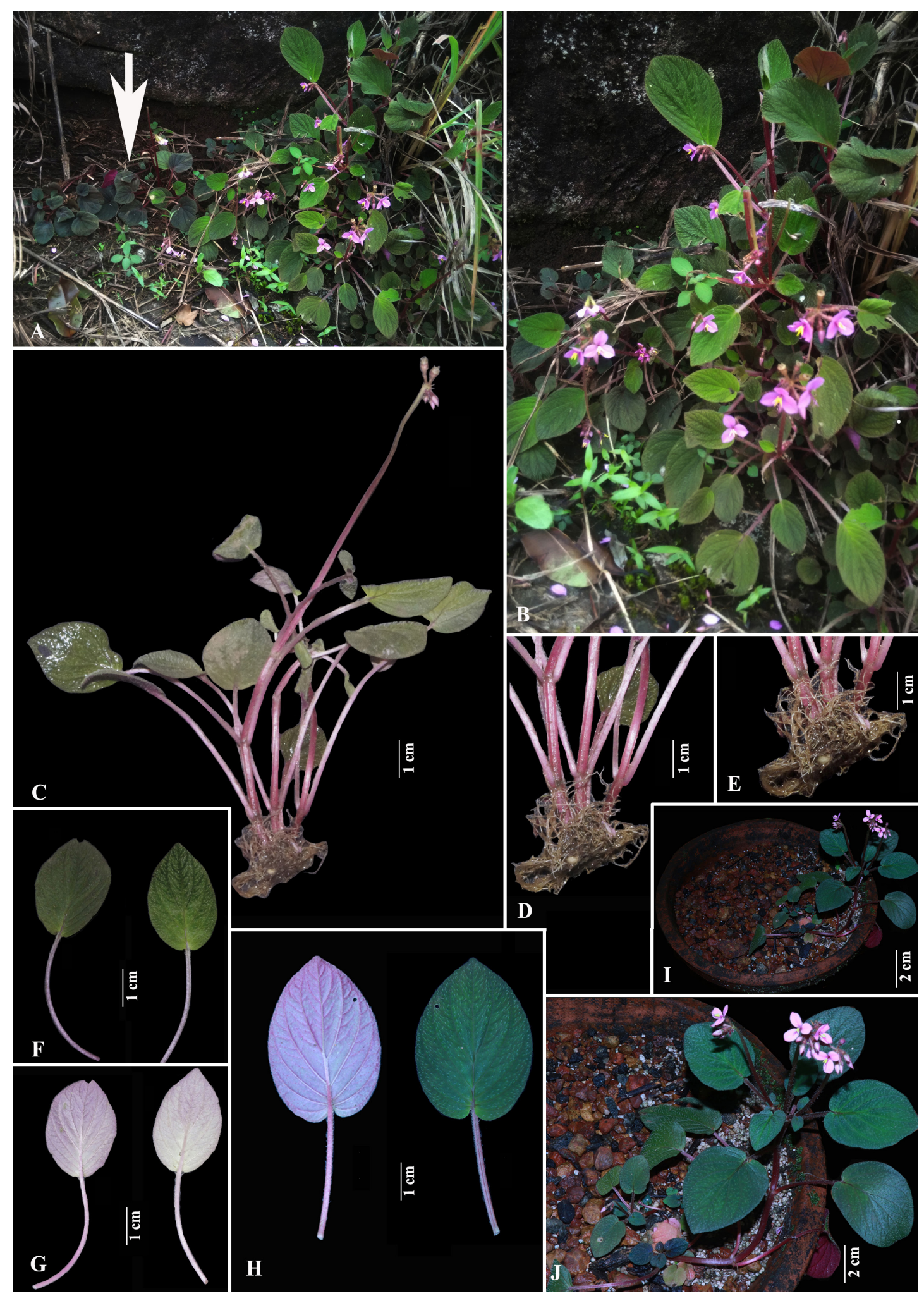

Fig. 2. Sonerila longipedunculata Resmi \& Nampy sp. nov. A-B. Plants in natural habitat, see also S. raghaviana Ratheesh et al. nearby (white arrow). C. Habit. D-E. Base of stem showing tuberous root stock. F-G. Leaves, adaxial and abaxial views. H. Leaves, abaxial and adaxial views showing venation. I-J. Plants under cultivation. Photographs by Resmi S. based on Resmi S. \& Santhosh Nampy 151222 (CALI). 


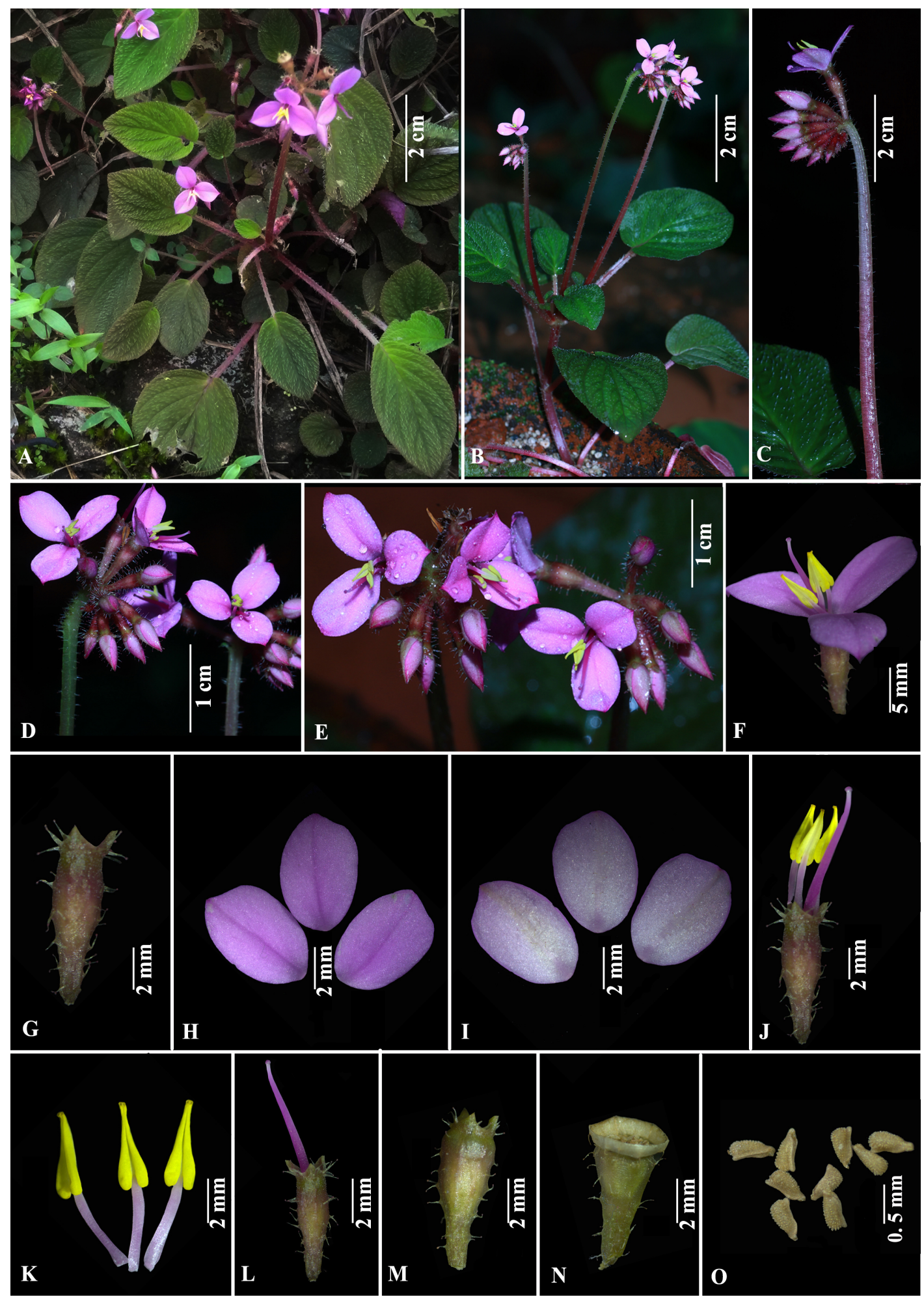

Fig. 3. Sonerila longipedunculata Resmi \& Nampy sp. nov. A. Habit. B. Plant with three inflorescences emerging from the distal node. C. Inflorescence. D-E. A portion of the inflorescence showing buds, flowers with glandular trichomes on peduncle, hypanthium and the abaxial surface of petals. F. Single flower. G. Hypanthium. H. Petals, adaxial view. I. Petals, abaxial view. J. Hypanthium with stamens and pistil. K. Stamens. L. Pistil. M. Capsule. N. Dehisced capsule. O. Seeds. Photographs by Resmi S. based on Resmi S. \& Santhosh Nampy 151222 (CALI). 


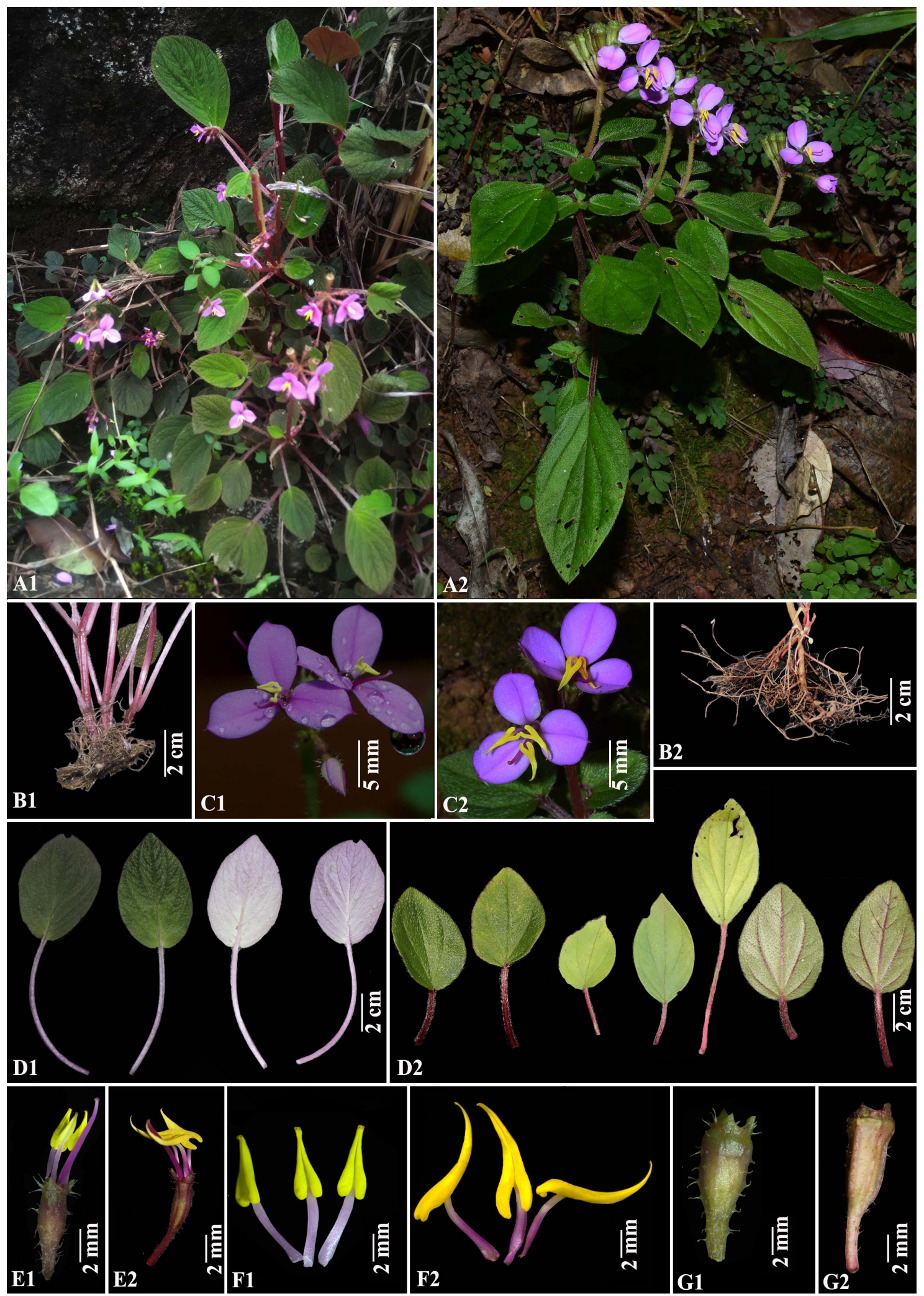

Fig. 4. Comparison between Sonerila longipedunculata Resmi \& Nampy sp. nov. (A1-G1) and S. travancorica Bedd. (A2-G2). A. Habit. B. Root stock. C. Flowers. D. Leaves, adaxial and abaxial views. E. Hypanthium with stamens and pistil. F. Stamens. G. Capsule. A1-G1 based on Resmi \& Santhosh Nampy 151222; A2-G2 based on Resmi S. \& Santhosh Nampy 151284 (CALI). 
Table 1. Comparative morphological features of Sonerila longipedunculata Resmi \& Nampy sp. nov. and $S$. travancorica Bedd.

\begin{tabular}{|c|c|c|}
\hline Characters & S. longipedunculata & S. travancorica \\
\hline Root stock & tuberous & not tuberous \\
\hline Stem & $\begin{array}{l}\text { fleshy with dense white or claret-coloured } \\
\text { bristles; internodes } 2-4 \mathrm{~cm} \text { long }\end{array}$ & $\begin{array}{l}\text { woody with dense long white hairs; } \\
\text { internodes } 2.5-6.5 \mathrm{~cm} \text { long }\end{array}$ \\
\hline Petiole & $5-9 \mathrm{~cm}$ long & $2-7 \mathrm{~cm}$ long \\
\hline Lamina & $\begin{array}{c}\text { ovate to cordate, margin serrate, bullate } \\
\text { when mature }\end{array}$ & $\begin{array}{c}\text { ovate to elliptic, margin serrulate, } \\
\text { velvety when mature }\end{array}$ \\
\hline Peduncle & $\begin{array}{l}10-16 \mathrm{~cm} \text { long, angular, longer than } \\
\text { petiole, densely glandular-pubescent }\end{array}$ & $\begin{array}{l}3-6 \mathrm{~cm} \text { long, terete, shorter or equal to } \\
\text { petiole, densely eglandular-pubescent }\end{array}$ \\
\hline Hypanthium & 3-ribbed & 6-ribbed \\
\hline Petal & $\begin{array}{l}\text { ovate to elliptic, acute to mucronate } \\
\text { at apex }\end{array}$ & $\begin{array}{c}\text { ovate to broadly ovate, mucronate to } \\
\text { emarginate at apex }\end{array}$ \\
\hline Anther & acute at apex & acuminate to rostrate at apex \\
\hline Capsule & 3-ribbed & 6-ribbed \\
\hline
\end{tabular}

species (Lundin 1983), but also reported in species from the Malay Peninsula, Vietnam and Cambodia (Ridley 1912; Pham 2003; Cho et al. 2015; Van Dang et al. 2016). These tubers, with the arrival of the monsoon, produce new stem and tufts of roots. The species of Sonerila from India are mostly pedunculate (with terete or angular peduncles) and rarely sub-sessile. The longer peduncles $(10-16 \mathrm{~cm})$ and petioles $(5-9 \mathrm{~cm})$ further distinguish the new species, and these traits are not described in any other caulescent herbaceous species, other than the suffrutescent or woody species of Indian Sonerila. Sonerila longipedunculata sp. nov. has fleshy and simple stems, which occasionally branch at distal nodes and become procumbent with roots arising from many points along the stem basally, when grown in the greenhouse. Sonerila longipedunculata sp. nov. is also similar to S. raghaviana Ratheesh, Sunil, Nandakumar \& Shaju described by Narayanan et al. (2014) in the hair pattern and floral features, but differs from it by the plants being caulescent (vs acaulescent/ scapigerous). A comparison of diagnostic characters between $S$. longipedunculata sp. nov. and $S$. travancorica is provided in Table 1.

Sonerila travancorica Bedd.

Figs 1, 4A2-G2, 5-7

Icones plantarum Indiae Orientalis: or Plates and Descriptions of New and Rare Plants, from Southern India and Ceylon: 33, tab. 156 (Beddome 1871). - Type: INDIA - Kerala, Attraymallay ghat/ Travancore; s.d.; Beddome 3023 \& 3022; lectotype: here designated, BM[BM000944457]! (digital image); isolectotype: BM[BM000793170]! (digital image).

Sonerila longipetiolata Josephine, Manickam, Murugan, Sundaresan \& Jothi, Journal of Bombay Natural History Society 100 (1): 81 (Josephine et al. 2003) syn. nov. - Type: INDIA • Tamil Nadu, Kanyakumari district, Muthukuzhivayal path; 22 Dec. 1999; V. Sundaresan \& M.M. Josephine 20104; holotype: XCH!.

\section{Additional material}

INDIA - Kerala, Thiruvananthapuram Dist., Athirumala; 6 Feb. 1988; N. Mohanan 9407; TBGT • ibid.; 6 Feb. 1988; N. Mohanan 9454; TBGT • ibid.; 18 Jan. 1993; N. Mohanan 11230; TBGT • ibid.; 
16 Mar. 2016; Prasobh P., Alfred Joe, Shinoj P. \& Resmi S. 143854; CALI • Pongalappara; 9 Jan. 1996; E.S. Santhosh Kumar 25592; TBGT • Tamil Nadu, Tirunelveli Dist., Agasthyamalai, Tirunelveli; 22 May 1901; s.coll. 2921; MH • Muthukuzhi; 19 Jan. 1978; A.N. Henry 52455; MH • Muthukuzhivayal path, Rajanagappara; 14 Aug. 2018; Resmi S. \& Santhosh Nampy 151288; CALI • ibid.; 18 Feb. 2019; Resmi S. \& Santhosh Nampy 168265; CALI • ibid.; 6 Apr. 2019; Resmi S. \& Santhosh Nampy 168280; CALI - Sengaltheri to Natterikal; 11 Feb. 1983; E. Vajravelu 76549; MH • Thazaiodai forest, Sengaltheri; 14 Feb. 1983; E. Vajravelu 80663; MH • Tirunelveli hills; Feb. 1943; Miss. E. Bowden s.n.; MH • Upper Kodayar; 21 Mar. 1981; A.N. Henry \& M.S. Swaminathan 70374; MH • ibid.; near Kakkachi Bungalow; 14 Aug. 2018; Resmi S. \& Santhosh Nampy 151284; CALI • ibid.; 18 Feb. 2019; Resmi S. \& Santhosh Nampy 168263; CALI • ibid.; 6 Apr. 2019; Resmi S. \& Santhosh Nampy 168276; CALI • Way to Muthukuzhivayal; 14 Mar. 1979; A.N. Henry 60682; MH.

\section{Notes on phenology and habitat}

Sonerila travancorica was collected with flowers and fruits from January to April. This endemic species is found only in the Agasthyamala Biosphere reserve in the southern Western Ghats (Fig. 1). Sonerila travancorica occurs in shady terrestrial habitats, but occasionally is found on the base of tree trunks or rocks with a relatively thick mossy substratum. It grows along the margins of sholas and near streams, waterfalls or dam areas at elevations above $1200 \mathrm{~m}$. It is found in association with Sonerila brunonis Wight \& Arn. (Melastomataceae), Digitaria ciliaris (Retz.) Koeler, Bambusa Schreb. sp. (both Poaceae), Impatiens L. sp. (Balsaminaceae A.Rich.), and certain mosses.

\section{Provisional conservation status}

This species is known from six locations in Agasthyamala Biosphere reserve in Kerala and Tamil Nadu. The estimated Extent of Occurrence (EOO) is ca $300 \mathrm{~km}^{2}$ and Area of Occupancy (AOO) is $12 \mathrm{~km}^{2}$. The authors surveyed three locations and found a total of 230 mature plants. Since these locations are inside a protected area, the risk of a decline due to anthropogenic activity is small. Based on the above data, the species is provisionally assessed here as Endangered (EN) B1ab(iii, iv, v), D (IUCN 2019).

\section{Discussion}

The genus Sonerila displays a wide morphological diversity and $S$. longipedunculata sp. nov. is recognised as a new species, thanks to extensive field work across India designed to generate a modern, comprehensive taxonomic treatment of the genus. Two other taxa, S. travancorica and S. longipetiolata, were examined and re-evaluated in this study.

Sonerila travancorica is exceptionally variable in its vegetative and floral morphology, including the shape of lamina (ovate to elliptic), base of lamina (equal or unequal and narrow to sub-rounded to cordate), length of petiole (2-7 cm long), colour and apex of the petals (dark pink to pale pink and mucronate to emarginate at apex), and number of flowers (4-16).

Sonerila longipetiolata was described by Josephine et al. (2003) from Muthukuzhivayal in Tirunelveli district of Tamil Nadu. During our botanical explorations in different parts of the southern Western Ghats, we studied a large number of specimens of this species from different areas of Kodayar, including the type locality (Kakkachi, Muthukuzhivayal and Kodayar Dam areas). A critical examination of protologues, type specimens and living material showed that the characters used to delimit $S$. longipetiolata fall within the range of $S$. travancorica, hence $S$. longipetiolata is reduced to a synonym of $S$. travancorica.

Sonerila travancorica was originally described by Beddome (1871) who cited the type locality as "Travancore mountains (Attraymallay), 3500-5000 feet" but did not specify a holotype. The main set of Beddome's collections (including types) is known to be at BM, K and CAL (Stafleu \& Cowan 1976). We 


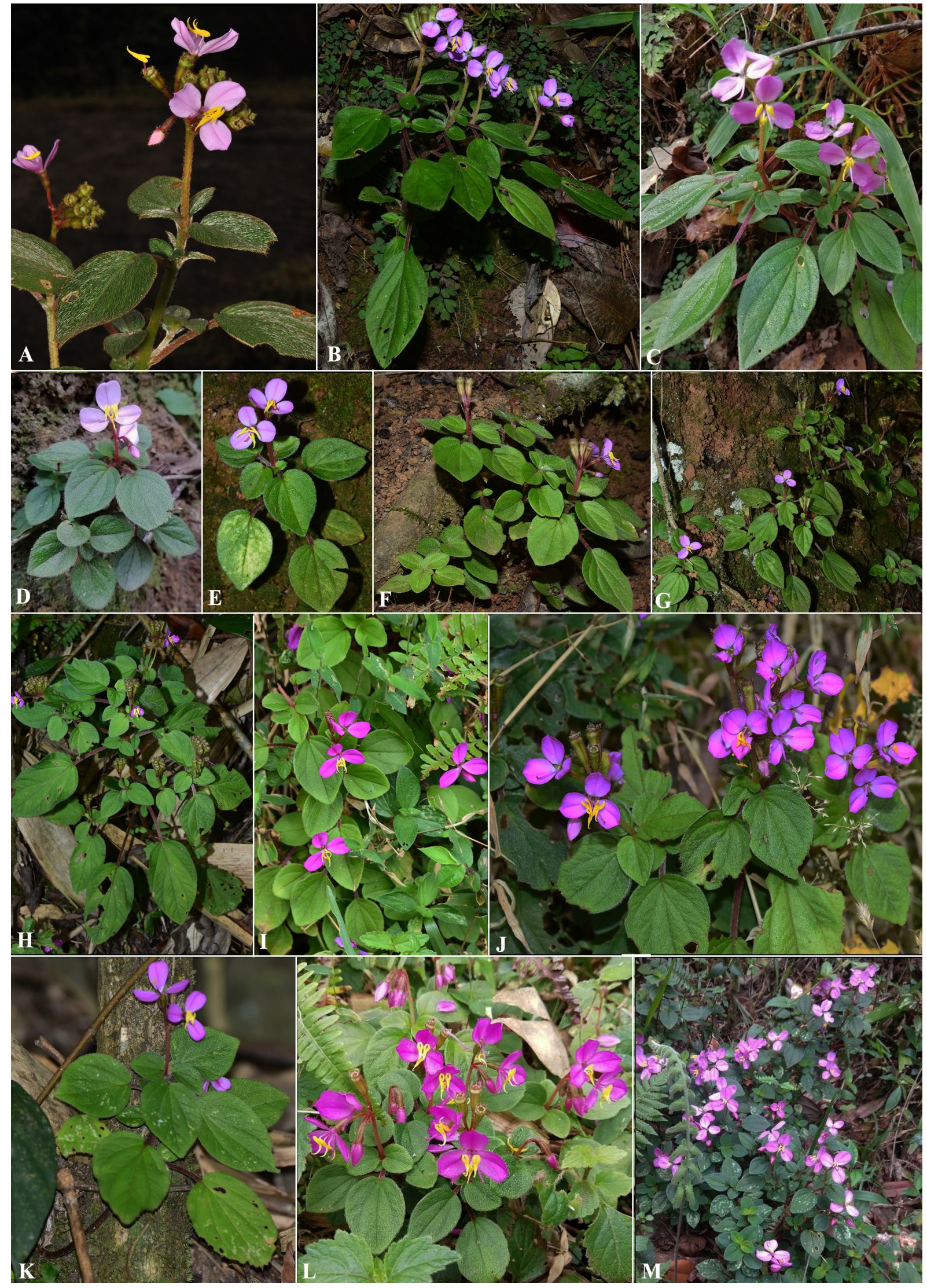

Fig. 5. Sonerila travancorica Bedd.; variations in habit. 


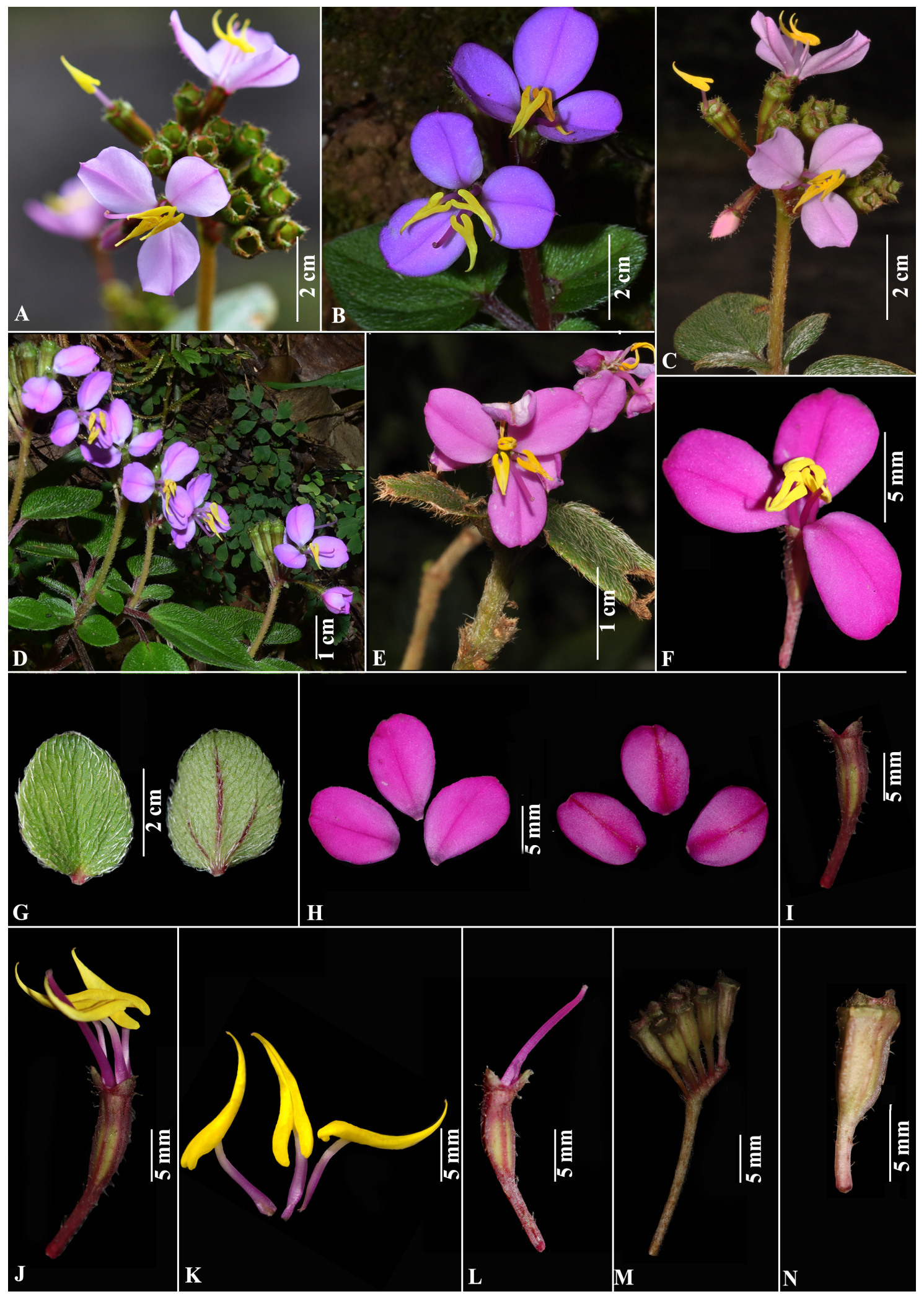

Fig. 6. Sonerila travancorica Bedd. A-D. Inflorescences showing flowers with emarginated and mucronate petals. E-F. Flowers. G. Lamina with dense long white hairs. H. Petals, adaxial and abaxial views. I. Hypanthium. J. Hypanthium with stamens and pistil. K. Stamens. L. Pistil M. Immature capsules. N. Mature capsule. Photographs: A, C, E by Prashob P.; B, D, F-N by Resmi S. 


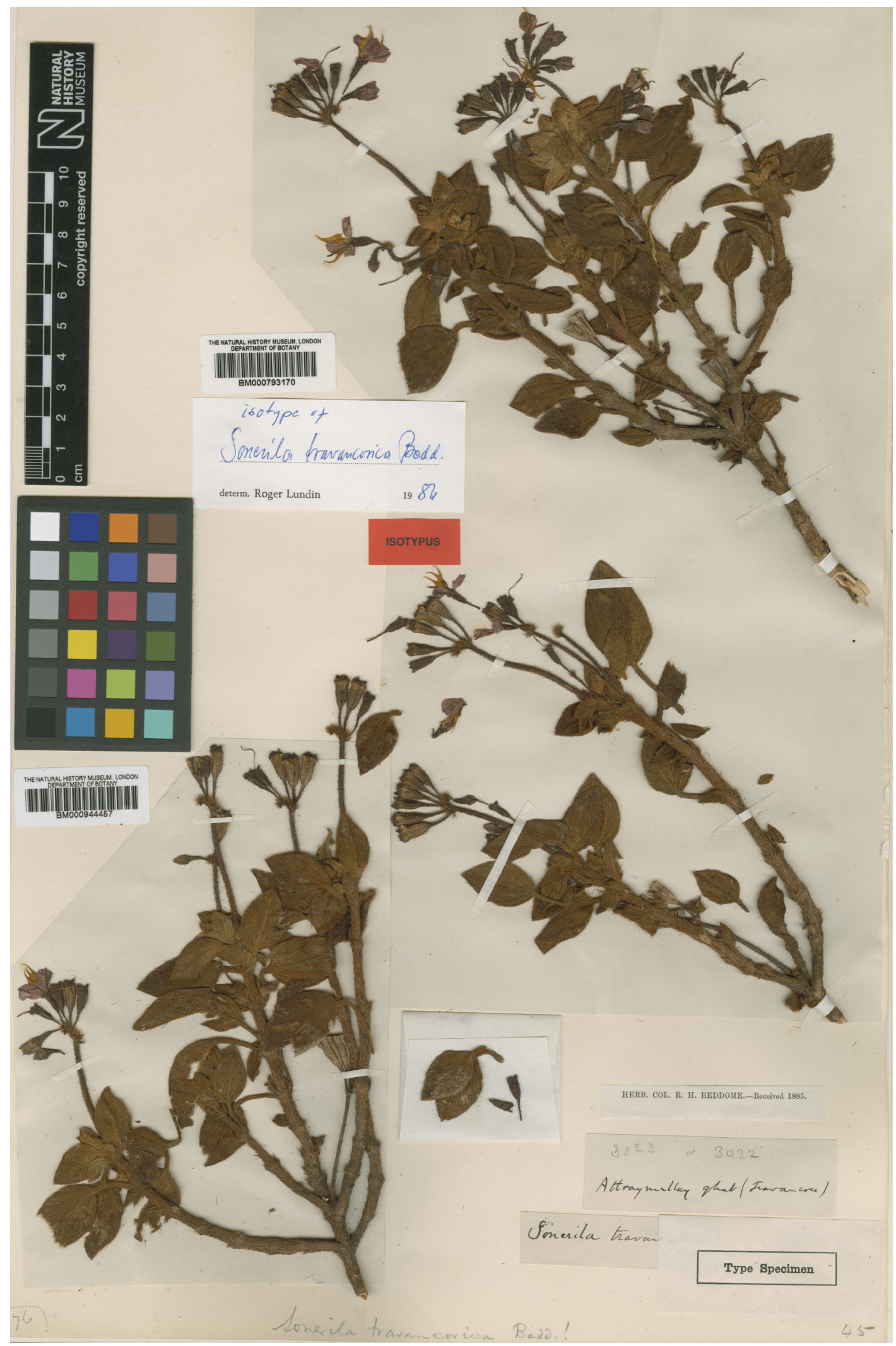

Fig. 7. Lectotype (BM000944457) and isolectotype (BM000793170) of Sonerila travancorica Bedd., Beddome 3023 \& 3022 (BM); (C) The Board of Trustees for the Natural History Museum, London. Reproduced with permission. 
have found one specimen at $\mathrm{K}$ (K000867664) and two specimens at BM mounted on the same sheet with two barcodes numbers (BM000793170 and BM000944457), which bears a field note "Attraymallay ghat/ Travancore 3023 \& 3022" in Beddome's handwriting, and two labels "Herb. Col. R.H. BeddomeReceived 1885" and "Type specimen". The sheet K000867664 bears an annotation "115- from Major Beddome, Travancore 4000ft, 4/1870". We have selected the specimen BM000944457 as the lectotype because it explicitly mentions the type locality and therefore, it represents the best choice among the available material.

\section{Acknowledgements}

The authors are thankful to the Head of the Department of Botany, University of Calicut, for facilities; the curators of the herbaria at $\mathrm{K}, \mathrm{BM}, \mathrm{CALI}, \mathrm{MH}, \mathrm{CAL}, \mathrm{TBGT}$ and $\mathrm{XCH}$ for permitting us to consult the specimens; Kerala and Tamil Nadu Forest Departments for permission to conduct field studies, in particular the Divisional Forest Officer, Range Forest Officer and all other forest officers and watchers of South Wayanad, Kalakkad Mundanthurai Tiger Reserve for various assistance during fieldwork; Adv. Athira P.B., Ms. Aswathi Ganga, Mrs. Dani Francis, Mr. Akhil M.K., Mr. Javad P. and Mr. Aneez for various help during fieldwork. SN is thankful to the Science Engineering Research Board (SERB), New Delhi, for funding (Sanction No: EMR/2016/007346, dated 29 October 2018). SR is grateful to the International Association for Plant Taxonomy for the IAPT Research Grant 2020 and to the Government of Kerala for financial support.

\section{References}

Beddome R.H. 1871. Icones plantarum Indiae Orientalis: or Plates and Descriptions of New and Rare Plants, from Southern India and Ceylon. Gantz Brothers, Mandras.

Cellinese N. 1997. Notes on the systematics and biogeography of the Sonerila generic alliance (Melastomataceae) with special focus on fruit characters. Tropical Biodiversity 4 (1): 83-93.

Cho S.H., Lee J.H., Won H., Phourin C. \& Kim Y.D. 2015. Sonerila bokorense (Melastomataceae), a new species from Cambodia. Phytotaxa 222 (4): 295-299. https://doi.org/10.11646/phytotaxa.222.4.8

Clarke C.B. 1879. Sonerila. In: Hooker J.D. (ed.) The Flora of British India Vol. 2: 529-540. L. Reeve \& Co., London.

Cogniaux A.C. 1891. Sonerila (Melastomataceae). In: Candolle A.P. de \& Candolle C. de (eds) Monographiae Phanerogamarum Vol. 7: 490-516. G. Masson, Paris.

Forman L. \& Bridson D. 1989. The Herbarium Handbook, $1^{\text {st }}$ Edition. Royal Botanic Gardens, Kew.

Gamble J.S. 1919. Flora of the Presidency of Madras Vol. 1: 497-500. Adlard \& Son Limited, London.

IUCN Standards and Petitions Committee. 2019. Guidelines for using the IUCN Red List Categories and Criteria. Version 14. Prepared by the Standards and Petitions Committee. Available from http://www.iucnredlist.org/documents/RedListGuidelines.pdf [accessed 20 Jun. 2020].

Josephine M.M., Manickam V.S., Murugan C., Sundaresan V. \& Jothi G.J. 2003. Sonerila longipetiolata Manickam et al., a new species of Melastomaceae from Tamil Nadu, India. Journal of the Bombay Natural History Society 100 (1): 81-83.

Lundin R. 1983. Taxonomy of Sonerila (Melastomataceae) in Ceylon. Nordic Journal of Botany 3: 633-656. https://doi.org/10.1111/j.1756-1051.1983.tb01475.x

Manickam V.S., Murugan C. \& Jothi G.J. 2008. Flora of Tirunelveli hills Vol. 1 Polypetalae: 410-415. Bishen Singh Mahendra Pal Singh, Dehra Dun. 
Mohanan M. \& Henry A.N. 1994. Flora of Thiruvananthapuram: 199-202. Botanical Survey of India, Kolkata.

Mohanan N. \& Sivadasan M. 2002. Flora of Agasthyamala: 282-285. Bishen Singh Mahendrapal Singh, Dehra Dun.

Nair N.C. \& Henry A.N. 1983. Flora of Tamil Nadu, India. Series I: Analysis: 163-165. Botanical Survey of India, Southern Circle, Coimbatore.

Narayanan R.M.K., Sunil C.N., Nandakumar M.K., Shaju T., Mini V., Satheesh K.T. \& Balakrishnan V. 2014. Sonerila raghaviana sp. nov. (Melastomataceae), a new species from southern Western Ghats of Karnataka, India. International Journal of Advanced Research 2: 772-777.

Pham H.H. 2003. An Illustrated Flora of Vietnam Vol. 2: 90-92 \& 775-777. Young Publishing House, Ho Chi Minh.

QGIS Quantum GIS Development Team. 2020. Quantum GIS geographic information system. Version 3.12.2.

Resmi S. \& Nampy S. 2018. Lectotypification of four names in Sonerila (Melastomataceae). Phytotaxa 375 (2): 165-170. https://doi.org/10.11646/phytotaxa.375.2.3

Resmi S., Manudev K.M., Pramod C. \& Nampy S. 2018. A new species of Sonerila (Melastomataceae: Sonerileae) from southern Western Ghats, India. Phytotaxa 333 (2): 235-242.

https://doi.org/10.11646/phytotaxa.333.2.7

Ridley H.N. 1912. New and Rare Malayan Plants (Series VI.). Journal of the Straits Branch of the Royal Asiatic Society 61: 1-43.

Stafleu F.A. \& Cowan R.S. 1976. Taxonomic Literature: A Selective Guide to Botanical Publications and Collections with Dates, Commentaries and Types, Second Edition Vol. 1: A-G. Regnum Vegetabile 94. Bohn, Scheltema \& Holkema, Utrecht. https://doi.org/10.5962/bhl.title.48631

Stapf O. 1892. On the Sonerileae of Asia. Annals of Botany (Oxford) 6: 291-323.

https://doi.org/10.1093/oxfordjournals.aob.a090681

Stearn W.T. 1992. Latín Botánico: Historia, Gramática, Sintaxis, Terminología y Vocabulario. Omega, David \& Charles, London.

Thiers B. continuously updated. Index Herbariorum: A Global Directory of Public Herbaria and Associated Staff. New York Botanical Garden's Virtual Herbarium.

Available from http://sweetgum.nybg.org/science/ih/ [accessed 20 Jun. 2020].

Triana J.J. 1871. Les Melastomacées. Transactions of the Linnean Society of London 28: 1-188.

https://doi.org/10.1111/j.1096-3642.1871.tb00222.x

Turland N.J., Wiersema J.H., Barrie F.R., Greuter W., Hawksworth D.L., Herendeen P.S., Knapp S., Kusber W.-H., Li D.-Z., Marhold K., May T.W., McNeill J., Monro A.M., Prado J., Price M.J. \& Smith G.F. 2018. International Code of Nomenclature for Algae, Fungi, and Plants (Shenzhen Code) Adopted by the Nineteenth International Botanical Congress Shenzhen, China, July 2017. Koeltz Botanical Books, Glashütten. https://doi.org/10.12705/Code.2018

Van Dang S., Nguyen H.Q., Pham H.D., Pham V.N., Mai T. \& Hoang N.S. 2016. Two new records for the flora of Vietnam: Sonerila (Melastomataceae) and Erycibe (Convolvulaceae). Plant Science Today 3 (4): 349-353. https://doi.org/10.14719/pst.2016.3.4.256

Vogel E.F. de 1987. Guidelines for the preparation of revisions. Manual of herbarium taxonomy theory and practice. UNESCO, Jakarta. 
Manuscript received: 15 August 2020

Manuscript accepted: 10 November 2020

Published on: 10 February 2021

Topic editor: Frederik Leliaert

Desk editor: Radka Rosenbaumová

Printed versions of all papers are also deposited in the libraries of the institutes that are members of the EJT consortium: Muséum national d'histoire naturelle, Paris, France; Meise Botanic Garden, Belgium; Royal Museum for Central Africa, Tervuren, Belgium; Royal Belgian Institute of Natural Sciences, Brussels, Belgium; Natural History Museum of Denmark, Copenhagen, Denmark; Naturalis Biodiversity Center, Leiden, the Netherlands; Museo Nacional de Ciencias Naturales-CSIC, Madrid, Spain; Real Jardín Botánico de Madrid CSIC, Spain; Zoological Research Museum Alexander Koenig, Bonn, Germany; National Museum, Prague, Czech Republic. 